\title{
DNA Methylation in Rat Liver by Daminozide, 1,1-Dimethylhydrazine, and Dimethylnitrosamine
}

\author{
Peter SagelsdorfF, Werner K. Lutz, ${ }^{1}$ AND CHRistian SCHLATter \\ Institute of Toxicology, Swiss Federal Institute of Technology and University of Zürich, \\ CH-8603 Schwerzenbach, Switzerland
}

Received February 8, 1988; accepted May 27, 1988

\begin{abstract}
DNA Methylation in Rat Liver by Daminozide, 1,1-Dimethylhydrazine, and Dimethylnitrosamine. SAGELSDORFF, P., LUTZ, W. K., AND SCHLATTER C. (1988). Fundam. Appl. Toxicol. 11, 723-730. [methyl $-^{14} \mathrm{C}$ ]Daminozide (succinic acid 2',2'-dimethylhydrazide; $37 \mathrm{mg} / \mathrm{kg}$ ), 1,1$\left[{ }^{14} \mathrm{C}\right]$ dimethylhydrazine (UDMH; $19 \mathrm{mg} / \mathrm{kg}$ ), and $\left[{ }^{14} \mathrm{C}\right]$ dimethylnitrosamine (DMNA; $0.1 \mathrm{mg} /$ $\mathrm{kg}$ ) were administered by oral gavage to male Sprague-Dawley rats. After $24 \mathrm{hr}$, the animals were killed and DNA was purified from the livers to constant specific radioactivity. After enzymatic degradation of the DNA to the 3'-deoxynucleotides the level of DNA methylation was determined by HPLC analysis. Radiolabeled 7 -methylguanine $(7 \mathrm{mG}$ ) was identified by cochromatography with unlabeled $7 \mathrm{mG}$ added as standard after acidic depurination of DNA and HPLC analysis of purines and apurinic acid. All three compounds were found to methylate DNA. The relative potencies were 1:47:4900 for daminozide:UDMH:DMNA. With [methyl- $\left.{ }^{3} \mathrm{H}\right] \mathrm{UDMH}$, the formation of $7 \mathrm{mG}$ was investigated as a function of dose administered, at 20,2 , and $0.2 \mathrm{mg}$ / $\mathrm{kg}$. The methylation of DNA was strictly proportional to the dose. The data were used to compare the level of DNA alkylation derived from residues of daminozide and UDMH in treated apple with the genotoxicity of the intake of $N$-nitroso compounds in Germany and Japan. It is estimated that these residues could lead to a DNA methylation in the liver of about $6 \%$ of an average exposure to DMNA. (c) 1988 Society of Toxicology.
\end{abstract}

Daminozide (succinic acid 2'-2'-dimethylhydrazide; trade name of formulation: Alar) is a plant growth regulator used in fruit and flower culture. Degradation of the parent compound in the fruits as well as in mammals may, under certain conditions, yield 1,1-dimethylhydrazine (unsymmetrical dimethylhydrazine, UDMH). The tumorigenic potential of various substituted hydrazine derivatives has been investigated, almost exclusively in one laboratory. Both daminozide (2\% in drinking water; Toth et al., 1977) and UDMH $(0.01 \%$ in drinking water; Toth, 1973) have been reported to induce angiosarcomas in mice in various organs, as well as

\footnotetext{
' To whom correspondence should be addressed.
}

tumors of the lungs, kidneys, and, for UDMH only, the liver. The studies are difficult to evaluate properly, however, because of the high toxicity of the treatments ( 23 and $8 \%$ survival at 70 weeks). Since daminozide was much less potent than UDMH (by a factor of about 200), it is possible that UDMH formed as a metabolite might be responsible for the effects induced by daminozide. In rats, UDMH was a very weak liver carcinogen, producing tumors only late in life. It was at least two orders of magnitude less potent than dimethylnitrosamine (DMNA) (Druckrey et al., 1967).

The putative mechanism of a tumor induction by UDMH might involve DNA methylation, in analogy to the mode of action of the potent carcinogen 1,2-dimethylhydrazine 
(symmetrical dimethylhydrazine, SDMH) (Lewis and Swenberg, 1983). Oxidative demethylation of UDMH can, in principle, lead to the same metabolic intermediates, so that a methylation of DNA by UDMH cannot be excluded.

The data obtained from in vitro tests on the genotoxicity of alkylhydrazines do not correlate with carcinogenicity (Kier et al., 1986), probably because the activation to the ultimate electrophiles does not proceed quantitatively. It was therefore the aim of this study to measure the methylating potency of daminozide and UDMH in vivo. Using the methyl-radiolabeled compounds, it was tested to what extent daminozide and UDMH methylate liver DNA in male Sprague-Dawley rats after oral administration. The results were used to estimate the level of DNA methylation induced by residues of daminozide and UDMH in fruits, and the DNA alkylation was compared with that arising from an average intake of dimethylnitrosamine (DMNA) with foods (Preussmann and Eisenbrand, 1984).

\section{MATERIALS AND METHODS}

Test compounds. The radiolabeled test compounds daminozide, UDMH, and DMNA were obtained from Chemsyn Science Labs., Lenexa, Kansas. The radiochemical purity of $\left[\right.$ methy $\left(-{ }^{14} \mathrm{C}\right]$ daminozide $(20.35 \mathrm{mCi}$ ) mmol) was $97.3 \%$, as determined by HPLC on a Lichrosorb RP18 $(7 \mu \mathrm{m})$ column $(4 \times 250 \mathrm{~mm})$, eluting at a flow of $1.5 \mathrm{ml} / \mathrm{min}$ with 65 parts $\mathrm{MeOH}$ and 35 parts $0.1 \%(w / v)$ aqueous SDS solution containing $0.1 \%(v / v)$ formic acid. Fractions of $1 \mathrm{~min}$ were collected and counted for radioactivity after the addition of $10 \mathrm{ml}$ Insta-Gel (Packard). The retention time for daminozide was $6 \mathrm{~min}$. The radiochemical purities of $\left[\right.$ methyl $\left[{ }^{14} \mathrm{C}\right]-$ UDMH (17.3 mCi/mmol), [methyl $-{ }^{14} \mathrm{C}$ ]DMNA (17.3 $\mathrm{mCi} / \mathrm{mmol})$, and $\left[\right.$ methyl $-{ }^{3} \mathrm{H}$ ]DMNA $(10.8 \mathrm{Ci} / \mathrm{mmol})$ were determined by HPLC on a Lichrosorb RP18 $(7 \mu \mathrm{m})$ column $(4 \times 250 \mathrm{~mm})$ eluting at a flow of $1.5 \mathrm{ml} / \mathrm{min}$, with a linear gradient over $15 \mathrm{~min}$ of $10-50 \%$ methanol in $50 \mathrm{mM}$ sodium phosphate buffer, $\mathrm{pH} 3.5$, containing $10 \mathrm{mM}$ octanesulfonic acid. The retention times were 3 and 9 min for DMNA and UDMH, respectively. The radiochemical purities were $99.8,95.9$, and $90 \%$ for [methyl- $\left.{ }^{14} \mathrm{C}\right] \mathrm{UDMH}$, [methyl- $\left.{ }^{14} \mathrm{C}\right]$, and [methyl${ }^{3}$ H]DMNA; no DMNA contamination could be detected in [methyl $\left.{ }^{14} \mathrm{C}\right]$ UDMH at a limit of detection of $0.006 \%$ [methyl $\left.-{ }^{14} \mathrm{C}\right] \mathrm{DMNA}$. The initial radiochemical purity of [methyl ${ }^{3} \mathrm{H}$ ]UDMH $(10 \mathrm{Ci} / \mathrm{mmol})$ was $76 \%$. This compound was purified before use by HPLC on a Partisil 10 SCX $(250 \times 4 \mathrm{~mm})$ column followed by a Partisil 5 ODS $3(250 \times 4 \mathrm{~mm})$ column (Whatman, NJ), eluting at a flow of $1.5 \mathrm{ml} / \mathrm{min}$ with a linear gradient over $20 \mathrm{~min}$ from 5 $\mathrm{m} M \mathrm{HCOOH} / \mathrm{NH}_{3}$, pH 3.6, to $300 \mathrm{~m} M \mathrm{HCOOH} / \mathrm{NH}_{3}$, $50 \%$ methanol, $\mathrm{pH}$ 3.6. The retention times were 9 and $28 \mathrm{~min}$ for DMNA and UDMH, respectjvely. The fractions containing UDMH were pooled and lyophilized. The radiochemical purity of the purified [methyl- $\left.{ }^{3} \mathrm{H}\right]-$ UDMH was $97.7 \%$ and contained less than $0.05 \%$ [methyl $-{ }^{3} \mathrm{H}$ ]DMNA.

Animals. Male Sprague-Dawley rats [Iva:SIV-50.SD] were obtained at weights of about $150 \mathrm{~g}$ from Ivanovas, Kissleg, FRG. They were held four per macrolone cage on sawdust for 1 week for acclimatization. They were fed Haltungsdiät "A" No. 343, Klingental Mühle AG. Kaiseraugst, Switzerland ad libitum and had free access to tap water.

Treatments. The rats received the labeled test compounds in about $1 \mathrm{ml} 0.01 \mathrm{~N} \mathrm{HCl}$ by oral gavage. [methyl${ }^{3} \mathrm{H}$ JUDMH was diluted with unlabeled UDMH (Fluka AG, Buchs, Switzerland) to the appropriate doses. The precise dose given to each individual animal was determined on the basis of the weight difference of the syringe before and after oral gavage. The values are listed in the tables. Animals receiving the ${ }^{14} \mathrm{C}$ label were placed in glass metabolism cages and the exhaled air was trapped with ethanolamine/methanol $(1+4 \mathrm{vol})$ to collect expired ${ }^{14} \mathrm{CO}_{2}$.

Isolation of chromatin. Twenty-four hours after the administration, the animals were killed by open heart puncture under ether anesthesia. The livers were excised and homogenized in a Teflon Potter-Elvehjem-type homogenizer at $4^{\circ} \mathrm{C}$. Chromatin was prepared according to Sagelsdorff $e$ al. (1983), essentially by precipitation with the nonionic detergent Nonidet-P40 (BDH Chemicals Ltd., Poole BH1 2 4NN, England). This pellet, containing about 2-3 mg DNA and $20-30 \mathrm{mg}$ protein per gram liver, was washed until the suspension contained $<1 \mu \mathrm{Ci}$ total radioactivity in order to remove the majority of noncovalently bound radioactivity.

Isolation of DNA. These steps were performed according to Sagelsdorff et al. (1983). Essentially, the chromatin pellet was homogenized in a Waring blender in $25 \mathrm{ml}$ lysing medium ( $1 \%$ (w/v) SDS, $10 \mathrm{~mm}$ EDTA, $8 \mathrm{M}$ urea in $0.24 \mathrm{M}$ sodium phosphate, $\mathrm{pH} 6.8$ ). Protein was extracted from the homogenate with chloroform/isoamyl alcohol/phenol (CIP), phenol was removed with diethylether, and the DNA was purified by adsorption on a hydroxylapatite column, dialysis, and precipitation with ethanol. The highly purified DNA (mostly double stranded, less than $0.2 \%$ protein, as shown with radiolabeled amino acid incorporation [Caviezel $e t$ al., 1984]) was dissolved in a $20 \mathrm{~mm}$ sodium succinate buffer, con- 
taining $8 \mathrm{mM} \mathrm{CaCl}_{2}, \mathrm{pH} 6.0$. The amount of DNA was determined by assuming an absorbance of 20 at $260 \mathrm{~nm}$ for a solution of $1 \mathrm{mg} \mathrm{DNA} / \mathrm{ml}$. Scintillation counting (Packard scintillation counter Tricarb 460 CD) was performed on an aliquot of the DNA solution after addition of $10 \mathrm{ml}$ Insta-Gel.

Repetitive purification of DNA. The remaining DNA solution was mixed with $25 \mathrm{ml}$ lysing medium, extracted twice with CIP and ether, and dialyzed and precipitated with ethanol. The DNA was again dissolved in a $20 \mathrm{mM}$ sodium succinate buffer, containing $8 \mathrm{mM} \mathrm{CaCl}_{2}, \mathrm{pH} 6.0$, and the specific activity of DNA was determined as described above.

Isolation of chromatin protein. Chromatin protein was precipitated with acetone from the first CIP extract (see above) and redissolved in $1 \%(w / v)$ aqueous SDS. The precipitation and redissolving steps were repeated five times. The last solution was diluted to $0.1 \%$ SDS and 1 $\mathrm{ml}$ was used for the scintillation counting. The amount of protein was determined with the Folin reagent.

Control experiments. (No. 1: Background radioactivity) DNA was isolated from an untreated animal. The radioactivity count-upon comparison with historical controls - was used to show that the workup of the DNA samples was performed without external contamination with radiolabels. (No. 2: Binding in vitro) The chromatin pellet isolated from the liver of an untreated rat was incubated for $15 \mathrm{~min}$ at $4^{\circ} \mathrm{C}$ with the radiolabeled supernatant from the first chromatin precipitation step of the DNA preparation from a treated animal. This allowed a check of whether radiolabel could contaminate DNA during the process of DNA isolation.

Analysis of DNA nucleotides. DNA $(0.1-1.3 \mathrm{mg})$ in 1 ml $20 \mathrm{~mm}$ sodium succinate buffer, containing $8 \mathrm{mM}$ $\mathrm{CaCl}_{2}, \mathrm{pH} 6.0$, was digested enzymatically with 2.5 units micrococcal endonuclease (Sigma, St. Louis, MO; No. N3755; EC 3.1.31.1.) and 0.05 units calf spleen exonuclease (Boehringer-Mannheim, Rotkreuz, $\mathrm{CH}$; No. 108251 ; EC 3.1.16.1) for $16 \mathrm{hr}$ at $37^{\circ} \mathrm{C}$. The resulting nucleotide mixture was separated by HPLC on a Lichrosorb RP18 $(10 \mu \mathrm{m})$ column $(8 \times 250 \mathrm{~mm})$, eluting at a flow of $3.5 \mathrm{ml} / \mathrm{min}$ with $50 \mathrm{mM}$ sodium phosphate buffer, pH 5.8, containing $3 \%$ methanol for $10 \mathrm{~min}$, followed by a linear gradient to $100 \%$ methanol over $40 \mathrm{~min}$. The absorbance was recorded at $254 \mathrm{~nm}$. Fractions of $2 \mathrm{~min}$ were collected. The retention times for the natural deoxynucleotides, deoxycytidine-3'-monophosphate, deoxyguanosine-3'-monophosphate, thymidine-3'-monophosphate, and deoxyadenosine-3'-monophosphate were at $4,7,10$, and $16 \mathrm{~min}$, respectively. The fractions which contained the normal nucleotides were pooled and concentrated to about $5 \mathrm{ml}$ at $60^{\circ} \mathrm{C}$ on an aspirator vacuum. The amount of deoxynucleotide mixture was determined by uv spectroscopy, taking as a standard an absorbance of 35 at $260 \mathrm{~nm}$ for a solution containing $1 \mathrm{mg}$ nucleotides/ml. Scintillation counting was performed after the addition of $10 \mathrm{ml}$ Insta-Gel. The background ra- dioactivity was determined by analyzing an inactive DNA digest. The standard deviation for each fraction was determined on the basis of 17 nucleotide analyses of control DNA hydrolysates. The standard deviation of a sample containing little radioactivity was assumed to be equal to the standard deviation of the background samples. The limit of detection for radioactivity in a fraction was then calculated on the basis of 2 SD.

Analysis of DNA purines. DNA $(0.1-1 \mathrm{mg})$ in $1.5 \mathrm{ml}$ $20 \mathrm{~mm}$ sodium succinate buffer, containing $8 \mathrm{mM} \mathrm{CaCl}_{2}$, $\mathrm{pH} 6.0$, was hydrolyzed chemically with $150 \mu l 1.0 \mathrm{~N} \mathrm{HCl}$ for $1 \mathrm{hr}$ at $70^{\circ} \mathrm{C}$. After neutralization with $150 \mu \mathrm{l} 1 \mathrm{~N}$ $\mathrm{NaOH}$ and addition of $100 \mu \mathrm{l}$ unlabeled 7-methylguanine $(0.05 \mathrm{mg} / \mathrm{ml})$, the resulting mixture of purines and apurinic DNA was separated by HPLC on a $\mu$ Bondapack $\mathrm{C} 18(10 \mu \mathrm{m})$ column $(7.8 \times 300 \mathrm{~mm})$ eluting at a flow of $3.5 \mathrm{ml} / \mathrm{min} 10 \mathrm{mM}$ ammonium phosphate buffer, $\mathrm{pH}$ 3.8 , containing $1 \%$ methanol for $15 \mathrm{~min}$, followed by a linear gradient to $100 \%$ methanol over $10 \mathrm{~min}$. The absorbance was recorded at $254 \mathrm{~nm}$. Fractions of 1 min were collected. The retention times for the purines guanine, adenine, and 7-methylguanine were at 6,9, and 13 min, respectively. The apurinic DNA eluted with methanol at 20 to $22 \mathrm{~min}$. Scintillation counting was performed after the addition of $10 \mathrm{ml}$ Insta-Gel. The background radioactivity was determined from an analysis of an unlabeled DNA hydrolysate. The standard deviation was determined on the basis of the eight purine analyses from control DNA hydrolysates. The variability of a sample containing little radioactivity was assumed to be equal to the variability of the background samples. The limit of detection for radioactivity in a fraction was then calculated on the basis of $2 \mathrm{SD}$.

Calculations. In order to correct the level of DNA methylations for the individual dose administered, an index value was defined. For the formation of 7-methylguanine $(7 \mathrm{mG})$, the index, $7 \mathrm{mGI}$, was defined as

$$
7 \mathrm{mGI}=\frac{\mu \mathrm{mol} 7-\mathrm{methylguanine} / \mathrm{mol} \mathrm{DNA} \text { nucleotide }}{\mathrm{mmol} \text { chemical applied } / \mathrm{kg} \text { body weight }} .
$$

In the conversion of the radioactivity data to molar units, an average molecular weight of 309 was assumed for a mixture of nucleotides in DNA, and it was taken into account that the molecules investigated contain two equivalent methyl groups only one of which was radiolabeled

$$
7 \mathrm{mGI}=2 \cdot \frac{\mathrm{dpm} 7 \mathrm{mG} / \mathrm{mg} \mathrm{DNA}}{\mathrm{dpm} / \mathrm{kg} \text { body weight }} \cdot 3.09 \cdot 10^{8}
$$

When using methyl- ${ }^{3} \mathrm{H}$-labeled compounds, a conversion of radioactivity to methyl groups cannot be made because the tritium label can partly be lost by tautomer formation at the hydrazone oxidation level $\left(\mathrm{CH}_{2}=\mathrm{N}-\right.$ $\mathrm{NH}_{2} \leftrightharpoons \mathrm{CH}_{3}-\mathrm{N}=\mathrm{NH}$ ). Therefore, a comparison of the results of the ${ }^{3} \mathrm{H}$-labeled compounds was made at the 
TABLE 1

RADJOACTIVITY AND LeVEL OF 7-METHYLGUANINE (7 mG) IN LIVER DNA ISOLATED FROM MALE SPRAGUEDAWLEY RATS, 24 hr AFTER ORAL ADMINISTRATION OF $\left[{ }^{14} \mathrm{C}\right]$ DaMINOZIDE, $\left[{ }^{14} \mathrm{C}\right]$ UDMH, AND $\left[{ }^{14} \mathrm{C}\right]$ DMNA

\begin{tabular}{ccccccc}
\hline Treatment & \multicolumn{2}{c}{ Daminozide } & \multicolumn{2}{c}{ UDMH } & \multicolumn{2}{c}{ DMNA } \\
\hline $\begin{array}{l}\text { Chemical dose (mg/kg) } \\
\text { Radioactivity dose } \\
\quad \text { (dpm/kg) }\end{array}$ & 36.8 & 36.5 & 15 & 23 & 0.1 & 0.1 \\
$\begin{array}{c}\text { DNA Ist purification } \\
\text { Specific activity } \\
\quad(\mathrm{dpm} / \mathrm{mg})\end{array}$ & $1.0 \times 10^{10}$ & $1.0 \times 10^{10}$ & $9.8 \times 10^{9}$ & $1.5 \times 10^{10}$ & $5.3 \times 10^{7}$ & $5.7 \times 10^{7}$ \\
$\begin{array}{c}\text { DNA 2nd purification } \\
\text { Specific activity } \\
\quad(\mathrm{dpm} / \mathrm{mg})\end{array}$ & 162 & 146 & 7440 & 11,350 & 623 & 612 \\
$\begin{array}{c}\text { Level of } 7 \mathrm{mG} \\
(7 \mathrm{mGI} \text { units) }\end{array}$ & 0.6 & 144 & 7380 & 10,920 & 614 & 621 \\
$\begin{array}{c}\text { Control data } \\
\text { Crude chromatin } \\
\text { protein (dpm/mg) }\end{array}$ & 620 & 440 & 4950 & 26 & 2790 & 2630 \\
\hline
\end{tabular}

${ }^{a}$ On the basis of purine analysis by HPLC. For definitions, see calculations under Materials and Methods.

level of the radioactivity data only and a tritium index was defined:

${ }^{3} \mathrm{H}$ index $=\frac{\mathrm{dpm}^{3} \mathrm{H} \text { in } 7 \mathrm{mG} / \mathrm{mg} \text { DNA }}{\operatorname{dpm}\left[{ }^{3} \mathrm{H}\right] \mathrm{UDMH} / \mathrm{kg} \text { body weight }}$.

\section{RESULTS}

DNA Methylation in the Liver after Treatment of Rats with Daminozide, UDMH, and $D M N A$

DNA radioactivity. Radioactivity was clearly detectable in all DNA samples. The specific radioactivity of the DNA remained constant between the first and the second purification rounds of the DNA. The data are summarized in Table 1 for $\left[{ }^{14} \mathrm{C}\right]$ daminozide, $\left[{ }^{14} \mathrm{C}\right]$ UDMH, and $\left[{ }^{14} \mathrm{C}\right] \mathrm{DMNA}$.

Radioactivity on the DNA isolated from an animal that has been treated with a radiolabeled substance is not necessarily due to covalent interactions of the test compound with DNA, but could be derived from three additional sources: (i) Noncovalent interaction of the test compound with DNA. This is unlikely because the respective control experiments (No. 2) showed that this contribution was negligible $(6 \mathrm{dpm} / \mathrm{mg}$ DNA for daminoz- ide; $90 \mathrm{dpm} / \mathrm{mg}$ DNA for UDMH) compared with the DNA radioactivities in the treated animals. (ii) Contamination of DNA with radiolabeled protein. The interaction of daminozide, UDMH, and DMNA or one of its radiolabeled metabolites with chromatin protein resulted in specific activities which were higher by a factor of less than 4 in protein than in DNA (last line in Table 1), so that the protein contamination of the DNA (shown earlier to be $<0.2 \%$ [Caviezel et al., 1984]) cannot have contributed substantially to the total DNA radioactivity. (iii) Biosynthetic incorporation of radioactivity into DNA and protein. This is a more likely source of a part of the observed DNA radioactivity if the compound or impurities administered are degraded to small molecules able to enter the pool of nucleic acid (and protein) precursors. Such is obviously the case with compounds that are degraded to yield ${ }^{14} \mathrm{CO}_{2}$, because, for instance, the carbon No. 6 of the purine bases adenine and guanine is taken from a $\mathrm{CO}_{2}$ molecule. Of the radioactivity dose administered, $1.3,17$, and $54 \%$ was exhaled within 24 $\mathrm{hr}$ in the form of ${ }^{14} \mathrm{CO}_{2}$ after the administration of $\left[{ }^{14} \mathrm{C}\right]$ daminozide, $\left[{ }^{14} \mathrm{C}\right] \mathrm{UDMH}$, and 


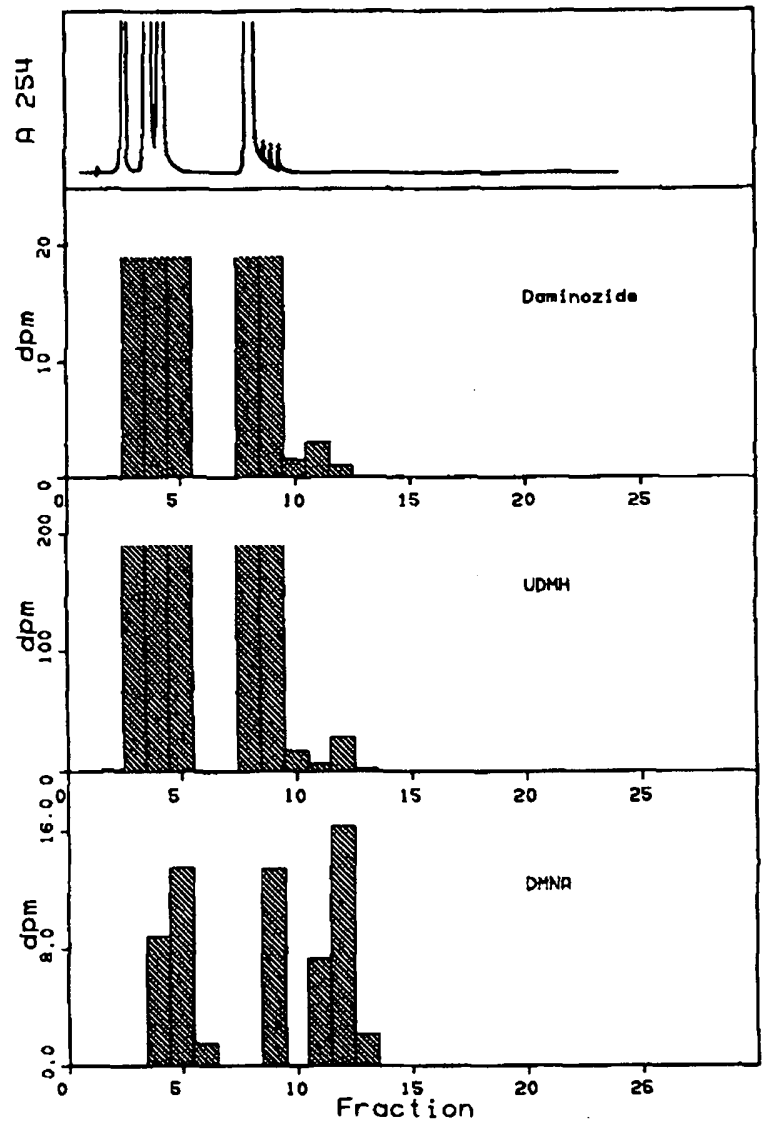

FIG. 1. HPLC elution profiles of deoxyribonucleotides obtained by enzymatic hydrolysis of DNA isolated from the liver of $\left[{ }^{14} \mathrm{C}\right]$ daminozide-, $\left[{ }^{14} \mathrm{C}\right] \mathrm{UDMH}-$, and $\left[{ }^{14} \mathrm{C}\right]$ DMNA-treated Sprague-Dawley rats. Top, absorbance profile (corresponding to the daminozide run), representing the natural deoxyribonucleotide-3'-monophosphates in the order $\mathrm{dCp}, \mathrm{dGp}, \mathrm{dTp}$, and $\mathrm{dAp}$. The small peaks following $\mathrm{dAp}$ represent deoxyribonucleosides obtained from partial loss of the 3'-phosphate group from the nucleotides. Charts 2 to $4,{ }^{14} \mathrm{C}$ activity in single fractions.

$\left[{ }^{14} \mathrm{C}\right] \mathrm{DMNA}$, respectively. Analysis of nucleotides and purines will be described below to show to what extent biosynthetic incorporation during DNA synthesis contributed to the total DNA radioactivity.

HPLC analysis of the DNA constituents. Enzymatic degradation to the deoxyribonucleotide-3'-monophosphates and separation of the four natural constituents $\mathrm{dCp}$, $\mathrm{dGp}, \mathrm{Tp}$, and dAp by HPLC resulted in reproducible elution profiles; the natural deoxyribonucleotides were localized by their absorbance at $254 \mathrm{~nm}$ (Fig. 1: fractions 3 to 9). The recovery of nucleotides was $95-99 \%$.
Most radioactivity eluted together with the natural nucleotides $(94,96$, and $58 \%$ for daminozide, UDMH, and DMNA, respectively. The remaining radioactivity $(6,4$, and 42\% for daminozide, UDMH, and DMNA, respectively) eluted later, in the region where the more lipophilic methylated nucleotides are expected to elute.

For identification of the major methylation product, DNA was depurinated and the resulting purines were separated by HPLC (Fig. $2)$. The recovery of radioactivity was 95$102 \%$, of which most cochromatographed with guanine, adenine, and with the apurinic acid. With $\left[{ }^{14} \mathrm{C}\right]$ daminozide, $6 \%$ of the radioactivity cochromatographed with added

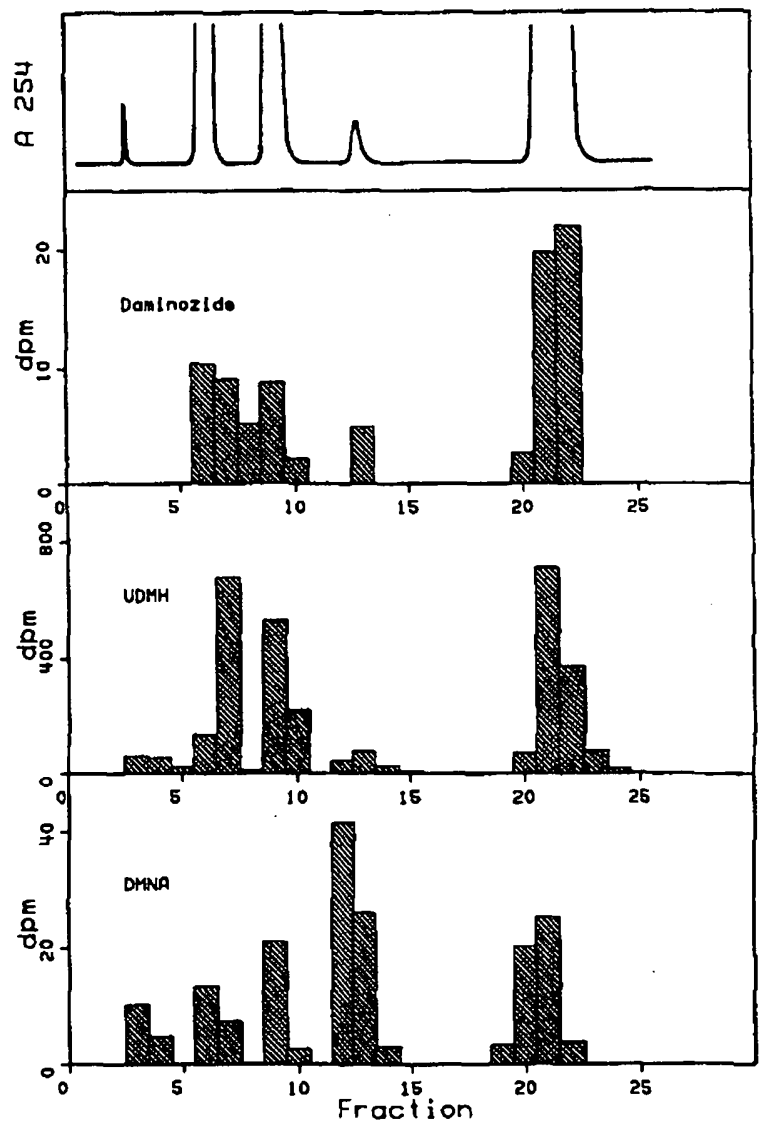

FIG. 2. HPLC elution profiles after depurination of liver DNA isolated from $\left[{ }^{14} \mathrm{C}\right]$ daminozide-, $\left[{ }^{14} \mathrm{C}\right]-$ UDMH-, and $\left[{ }^{14} \mathrm{C}\right] \mathrm{DMNA}$-treated Sprague-Dawley rats. Top, absorbance profile (corresponding to the daminozide run), representing (after the solvent peak) the purines $G$ and $A, 7$-methylguanine added as unlabeled standard, and the apurinic acid. Charts 2 to $4,{ }^{14} \mathrm{C}$ activity in single fractions. 
7-methylguanine. With $\left[{ }^{14} \mathrm{C}\right]$ UDMH and $\left[{ }^{14} \mathrm{C}\right] \mathrm{DMNA}$ the respective values were 4 and $39 \%$. These fractions determined for one specific methylated base, $7 \mathrm{mG}$, are very close to the values determined by nucleotide analysis. This is compatible with the expectation that $7 \mathrm{mG}$ represents the major methylation product in DNA.

Level of DNA methylation. The results indicate that most of the radioactivity determined on the DNA after oral administration of the ${ }^{14} \mathrm{C}$-labeled daminozide and UDMH was due to biosynthetic incorporation of metabolic breakdown products of ${ }^{14} \mathrm{C}$-labeled compounds into DNA. Only about 6 and 4\% of the radioactivity was due to methylation of DNA by daminozide and UDMH, respectively. The respective figure for the positive control carcinogen $\left[{ }^{14} \mathrm{C}\right] \mathrm{DMNA}$ was $39 \%$. Expressed in the units of the 7-methylguanine index, values of $0.55,26$, and 2700 resulted for daminozide, UDMH, and DMNA (Table 1). This means that a theoretical single dose of $1 \mathrm{mmol}$ compound per kilogram body weight would result in $0.55,26$, and 27007 -methylguanine molecules per $10^{6} \mathrm{nu}$ cleotides, under the assumption of a linear dose-binding relationship.

\section{Dose Dependence of the Methylation of DNA}

Since the dose of $\left[{ }^{14} \mathrm{C}\right] \mathrm{UDMH}$ administered was much higher than a potential human exposure it was considered important to investigate whether the formation of the ultimate methylating agent is proportional to the dose at lower dose levels. A tritium label was used because of the higher specific activity available, despite the possibility that this radiolabel can be lost by tautomer formation at the hydrazone oxidation level (daminozide and UDMH only). Twenty-four hours after oral administration of $0.2,2$, and $20 \mathrm{mg} / \mathrm{kg}$ $\left[{ }^{3} \mathrm{H}\right] \mathrm{UDMH}$, all DNA samples were radiolabeled (Table 2). The DNA was depurinated and the purines were separated by HPLC. With UDMH, $3-4 \%$ of the radioactivity eluted together with added unlabeled 7-methylguanine standard. When using [ $\left.{ }^{3} \mathrm{H}\right] \mathrm{DMNA}$ as positive control, $63 \%$ of the radioactivity cochromatographed with 7-methylguanine. The data were normalized to the individual dose administered by conversion to a ${ }^{3} \mathrm{H}$ in$\operatorname{dex}=\left({ }^{3} \mathrm{H} \mathrm{dpm}\right.$ in 7-methylguanine $/ \mathrm{mg}$ DNA)/(dpm [ $\left.{ }^{3} \mathrm{H}\right] \mathrm{UDMH} / \mathrm{kg}$ body wt). Similar values, around $5 \times 10^{-9}$, were obtained at all dose levels, showing that the DNA methylation was strictly proportional to the dose over the entire dose range. With $\left[{ }^{3} \mathrm{H}\right] \mathrm{DMNA}$, the ${ }^{3} \mathrm{H}$ index was $3.4 \times 10^{-6}$, i.e., higher by a factor of about 700 as compared to that of [ $\left.{ }^{3} \mathrm{H}\right] \mathrm{UDMH}$.

The radiosynthesis of UDMH used DMNA as an intermediate. Because of the high DNA methylating activity of DMNA it was of prime importance to exclude the possibility that DMNA contamination in UDMH could have been responsible for the DNA methylation observed. The purity checks showed that the maximum level of contamination was $0.006 \%$ for the ${ }^{14} \mathrm{C}$-labeled compound and $0.05 \%$ for $\left[{ }^{3} \mathrm{H}\right] \mathrm{UDM} H$. The DNA methylating potency of DMNA was 100 times higher than that of UDMH based on the ${ }^{14} \mathrm{C}$ data, with ${ }^{3} \mathrm{H}$, in terms of the tritium index, the difference was a factor of 700 . It can therefore be excluded that DMNA contaminations in UDMH simulated a DNA methylation by UDMH.

\section{DISCUSSION}

The results indicate that the administration of [methyl $\left.-{ }^{14} \mathrm{C}\right]$ daminozide and 1,1$\left[{ }^{14} \mathrm{C}\right]$ dimethylhydrazine result in the formation of ${ }^{14} \mathrm{C}$-labeled 7 -methylguanine in rat liver DNA. Upon comparison with the standard carcinogen dimethylnitrosamine, daminozide is about 5000 times less effective, while UDMH is about 100 times weaker with respect to DNA methylation. These potency differences are in good agreement with the doses required to induce liver tumors by DMNA and UDMH (Druckrey et al., 1967). 
TABLE 2

RADIOACTIVITY IN LIVER DNA AND 7-METHYLGUANINE ISOLATED FROM MALE SPRAGUE-DAWLEY RATS, $24 \mathrm{hr}$ AFTER ORAL ADMINISTRATION OF [ $\left.{ }^{3} \mathrm{H}\right]$ UDMH AND [ $\left.{ }^{3} \mathrm{H}\right] \mathrm{DMNA}$

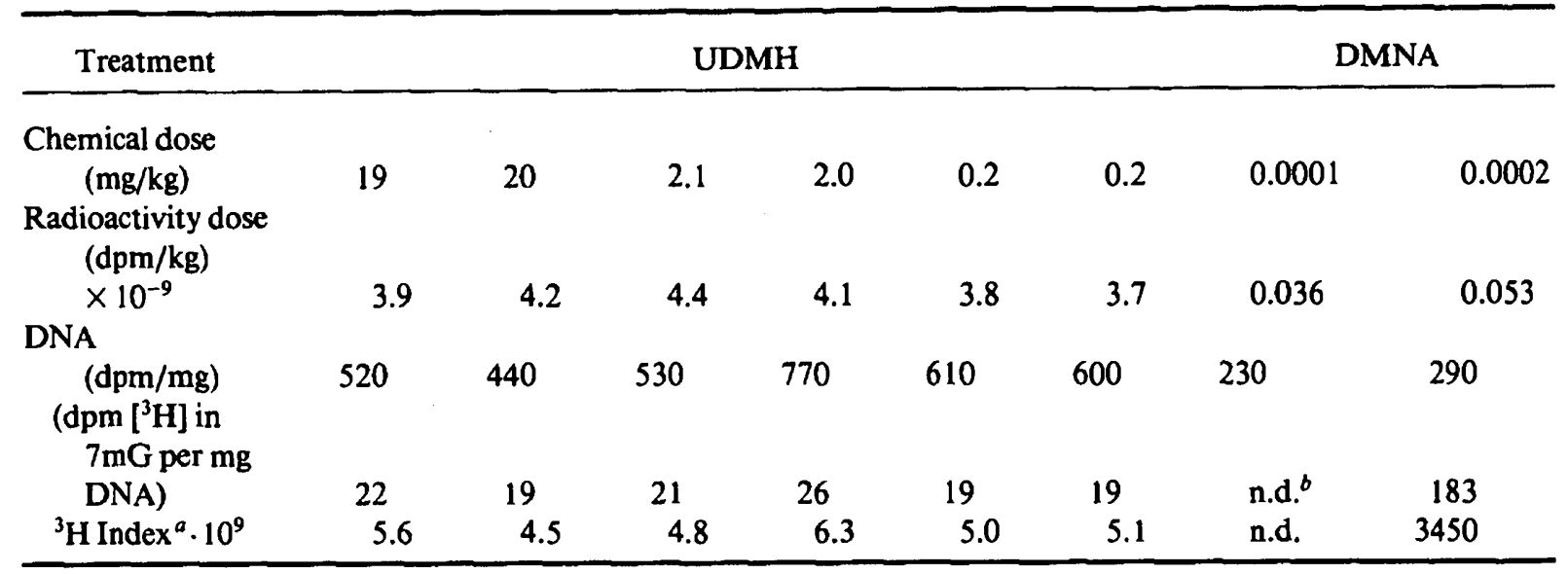

${ }^{a}$ For definition, see calculations under Materials and Methods.

${ }^{b}$ No data.

7-Methylguanine is the major methylation product if DNA is reacted with the methyldiazonium ion, but there is good evidence that DNA methylations other than at the 7 position of guanine are responsible for mutagenesis and carcinogenesis. For a comparison of the DNA methylation potency of daminozide and UDMH with DMNA, the present data on $7 \mathrm{mG}$ can be used because all these compounds most probably form the same ultimate methylating agent and therefore produce a similar ratio of uncritical to dangerous methylation products. It was also attempted to reach similar levels of total DNA methylations for all compounds by using lower doses of the more potent methylating agent DMNA.

Below, we attempt to use the data obtained in this study with rats for a risk estimation in humans. For this purpose, it must be assumed that human liver also contains the enzymes required for an activation of the compounds to methylating intermediates. In addition, a linear extrapolation will be used to estimate the DNA alkylation at low doses. Theoretical considerations and experimental data indicate that the activation and inactivation processes governing the formation of
DNA adducts do follow first-order kinetics in the low dose range (Lutz, 1987).

DMNA is found in a variety of food items, especially meat products and beer. An estimate of the average daily human intake in Germany was $0.6 \mu \mathrm{g}$ per person and day (Preussmann and Eisenbrand, 1984), corresponding to $1.4 \times 10^{-7} \mathrm{mmol} \cdot \mathrm{kg}^{-1} \cdot \mathrm{d}^{-1}$ for a $60-\mathrm{kg}$ person. The level of formation of $7 \mathrm{mG}$ induced by such a dose in liver DNA in the rat, $24 \mathrm{hr}$ after the administration, can be estimated by multiplying this dose with the $7 \mathrm{mG}$ index for DMNA, 2700 , to give $3.8 \times 10^{-4}$ $\mu \mathrm{mol} 7 \mathrm{mG} / \mathrm{mol}$ DNA nucleotides.

A similar estimation could be made for daminozide and UDMH. Based on residue data derived from the Federal Register (1984), the following estimation can be made: In a daily portion of $300-\mathrm{g}$ Alartreated apple assumed to contain $0.4 \mathrm{mg} / \mathrm{kg}$ daminozide and $0.008 \mathrm{mg} / \mathrm{kg}$ UDMH, 120 $\mu \mathrm{g}\left(7.5 \times 10^{-4} \mathrm{mmol}\right)$ daminozide and 2.4 $\mu \mathrm{g}\left(4.0 \times 10^{-5} \mathrm{mmol}\right)$ UDMH are taken up. Expressed per kilogram body weight and multiplied with the $7 \mathrm{mG}$ index, $2.3 \times 10^{-5}$ $\mu \mathrm{mol} 7 \mathrm{mG} / \mathrm{mol}$ DNA nucleotides result for daminozide and UDMH together. This is lower than the DNA alkylation exerted by 
an average DMNA exposure by a factor of about 17. Exposure to daminozide and UDMH from other sources can be evaluated in an analogous way.

The exposure to other $N$-nitroso compounds in the diet appears to be 10-50 times higher (Kawabata et al. 1984), on the order of $10^{-4}$ to $10^{-3} \mathrm{mmol}$ per person and day in Japan. If it is assumed that these $N$-nitroso compounds are of equal genotoxic potency as DMNA, daminozide plus UDMH residues in $300 \mathrm{~g}$ treated apple would lead to a DNA alkylation in the liver of $1 / 200$ to $1 / 1000$ of the environmental background exposure to $N$-nitroso genotoxins.

\section{ACKNOWLEDGMENT}

This work was supported by Uniroyal Chemical Company.

\section{REFERENCES}

CaVIezel, M., LUTz, W. K., Minini, U., AND SchlatTER, $C H$. (1984). Interaction of estrone and estradiol with DNA and protein of liver and kidney in rat and hamster in vivo and in vitro. Arch. Toxicol. 55, 97103.

Druckrey, H., Preussmann, R., IVANKovic, S., and SCHMÄHL, D. (1967). Organotrope carcinogene Wirkungen bei 65 verschiedenen N-Nitroso-Verbindungen an BD Ratten. Z. Krebsforsch. 69, 103-201.

Federal Register (1984). EPA Notice Initiating a Special Review of Pesticide Products Containing Daminozide (49 FR 29136, July 18, 1984). The Bureau of National Affairs, Inc. Washington, D.C. 20037. Issue of July 20, 1984, pp. 460-464.
Kawabata, T., Matsui, M., Ishibashi, T., and HaMANO, M. (1984). Analysis and occurrence of total Nnitroso compounds in the Japanese diet. In $N$-nitroso Compounds: Occurrence, Biological Effects and Relevance to Human Cancer. (I. K. O'Neill, R. C. vonBorstel, C. T. Miller, J. Long, and H. Bartsch, Eds.), pp. 25-31. IARC Sci. Publ. 57, Int. Agency Res. Cancer, Lyon.

KIER, L. E., BRUSiK, D. J., Auletta, A. E., Von Halle, E. S., BRown, M. M., Simmon, V. F., DUNKEL, V., McCann, J., Mortelmans, K., Prival, M., Rao, T. K., AND RAY, V. (1986). The Salmonella typhimurium/mammalian microsomal assay. A report of the U.S. Environmental Protection Agency Gene-Tox Program. Mutat. Res. 168, 69-240.

LEWIS, J. G., AND SWENBERG, J. A. (1983). The kinetics of DNA alkylation, repair and replication in hepatocytes, Kupffer cells, and sinusoidal endothelial cells in rat liver during continuous exposure to 1,2-dimethylhydrazine. Carcinogenesis 4, 529-536.

LUTZ, W. K. (1987). Quantitative Evaluation of DNAbinding data in vivo for low-dose extrapolations. Arch. Toxicol. Suppl. 11, 66-74.

PreussmanN, R., AND EIsenbrand, G. (1984). N-nitroso carcinogens in the environment. In Chemical Carcinogens (C. E. Searle, Ed.), pp. 829-868. ACS Monograph 182, American Chemical Society, Washington.

SagelsdorfF, P., Lutz, W. K., AND SChlatter, Ch. (1983). The relevance of covalent binding to mouse liver DNA to the carcinogenic action of hexachlorocyclohexane isomers. Carcinogenesis 4, 1267-1273.

TOTH, B. (1973). 1,1-Dimethylhydrazine (unsymmetrical) carcinogenesis in mice. Light microscopic and ultrastructural studies on neoplastic blood vessels. $J$. Natl. Cancer Inst. 50, 181-194.

Toth, B., WallCave, L., Patil, K., SChmeltz, I, AND HOFFMANN, D. (1977). Induction of tumors in mice with the herbicide succinic acid 2,2-dimethylhydrazide. Cancer Res. 37, 3497-3500. 